\title{
ANALISIS PENYERAPAN TENAGA KERJA SEKTOR PRIMER, SEKUNDER DAN TERSIER DI PROVINSI MALUKU
}

\author{
Tri Wahyuningsih \\ Dosen Jurusan IESP Fakultas Ekonomi, Universitas Iqra Buru (Namlea-Maluku) \\ Email: riz_180506@yahoo.com \\ HP. 08134323295
}

\begin{abstract}
One of the important basic requirements in the field of development economics in order to thrive and flourish in the long run is located on human resources in Indonesia, enough can be a potential, so that these resources have the capability and morale is quite large, which moves in an integrated and harmonious all activities, in order to cultivate and utilize other resources in the economic process. From the point of economy, social and political, areas that have experienced political and social instability such as the province of Maluku, the expansion of employment opportunities in the domestic absolutely necessary as a primary strategy. Thus analysis needed employment in the primary sector, secondary, tertiary Eden in Maluku province in 1997-2007 using qualitative research methods. The results showed that: First, there is a change of economic structure and employment. Second, the productivity of labor in the Province of Maluku is still low and there is potential for increased well-educated workforce. Third, economic conditions and growth rates of employment after the economic crisis and the regional autonomy is better than in times of crisis and before the regional autonomy.
\end{abstract}

Keywords : Tenaga Kerja, Sektor Primer, Sektor Sekunder, Sektor Tersier

Pembangunan nasional suatu bangsa yang dititik-beratkan pada bidang ekonomi akan dapat berlangsung dalam jangka panjang dan makin maju, jika dipenuhi sejumlah syarat pokok, diantaranya ada dua hal penting. Pertama, ada sumber daya manusia yang cukup banyak dan mempunyai kemampuan dan semangat kerja yang cukup besar, yang menggerakkan secara terpadu dan serasi semua kegiatan, guna mengolah dan memanfaatkan sumber daya lain dalam proses pembangunan. Kedua, ada pasar yang cukup besar untuk menjual barang dan jasa yang dihasilkan dalam pembangunan.

Indonesia menrupakan salah satu negara dengan penduduk terbanyak di dunia. Apabila jumlah penduduk yang besar tersebut dapat dioptimalkan 
pemanfaatannya dan diserasikan gerak langkahnya, merupakan potensi yang sangat besar. Dilain pihak, jumlah penduduk yang besar tersebut merupakan pasar potensial dalam negeri yang sangat menjanjikan. Hal ini dapat ditunjang, apabila penduduknya mempunyai tingkat pendapatan yang tinggi dan merata. Untuk dapat memberikan tingkat pendapatan yang memadai bagi penduduknya, salah satu cara yang dapat ditempuh adalah dengan menyediakan lapangan pekerjaan yang produktif dan remuneratif yang layak serta mendapatkan penghargaan dari masyarakat (productive, remunerative and rewarding employment).

Bagi negara yang berdaulat, mendapatkan pekerjaan merupakan hak setiap warga negara, dimana dengan pekerjaan tersebut setiap individu akan dapat memberikan ketentraman dan kepuasan batin, perasaan kepastian hidup, menumbuhkan rasa harga diri, serta membangkitkan semangat kerja yang tinggi. Dengan demikian, penyediaan lapangan kerja mempunyai peranan yang sangat penting dalam menunjang stabilitas sosial dan politik yang sehat dan dinamis, dimana kedua hal tersebut merupakan prasyarat utama dalam pembangunan. Dengan pemikiran tersebut, ditinjau dari sudut ekonomi, sosial dan politik, bagi negara yang berpenduduk besar seperti Indonesia dan daerah yang pernah mengalami ketidakstabilan sosial politik seperti provinsi Maluku, perluasan kesempatan kerja di dalam negeri mutlak diperlukan sebagai strategi utama. Baik dalam kerangka teoritis maupun kerangka empiris telah banyak dibuktikan bahwa tenaga kerja memiliki bagian yang tidak terpisahkan dalam pembangunan. Bahkan faktor tenaga kerja tidak saja dipandang sebagai satu bagian unit dalam penciptaan output (produksi) tetapi juga bagaimana kualitas tenaga kerja tersebut berinteraksi dengan faktor-faktor produksi lainnya untuk menciptakan nilai tambah (produktifitas). Berdasarkan alasan tersebut, maka tulisan ini bertujuan untuk menganalisis secara kualitatif tren penyerapan tenaga kerja di sektor primer, sekunder dan tersier di provinsi Maluku sebagai salah satu potensi dalam menunjang pembangunan nasional. 


\section{METODOLOGI PENELITIAN}

Di Indonesia, pengertian tenaga kerja (manpower) sudah sering dipergunakan. Tenaga kerja mencakup penduduk yang sudah atau sedang bekerja, yang sedang mencari pekerjaan, dan yang melakukan kegiatan lain, seperti bersekolah dan mengurus rumah tangga. Tiga golongan yang disebut terakhir (pencari kerja, bersekolah dan mengurus rumah tangga), walaupun sedang tidak bekerja, mereka dianggap secara fisik mampu dan sewaktu-waktu dapat ikut bekerja (Simanjutak, 1998).

Secara praktis pengertian tenaga kerja dan bukan tenaga kerja dibedakan hanya oleh batas umur. Tiap-tiap negara memberikan batasan umur yang berbeda. India misalnya menggunakan batasan umur tenaga kerja antara 14-60 tahun, sehingga orang yang berada di luar selang umur tersebut (dibawah 14 tahun dan diatas 60 tahun) digolongkan sebagai bukan tenaga kerja. Di Amerika Serikat, Jerman Barat, dn negara-negara Eropa yang lain, bagian penduduk yang termasuk usia kerja ialah kelompok umur 15-64 tahun (Ida Bagoes Mantra, 2004). Tujuan dari pemilihan batas umur tersebut adalah supaya definisi yang diberikan sedapat mungkin menggambarkan kenyataan yang sebenarnya. Tiap negara memilih batas umur yang berbeda karena, situasi tenaga kerja di masing-masing negara juga berbeda.

Di Indonesia semula dipilih batas umur minimum 10 tahun tanpa batas umur maksimum. Dengan demikian, yang dimaksud dengan tenaga kerja di Indonesia adalah penduduk yang berumur 10 tahun lebih. Penduduk yang berumur di bawah 10 tahun digolongkan sebagai bukan tenaga kerja. Pemlihan 10 tahun sebagai batas umur minimum adalah berdasarkan kenyataan bahwa dalam umur tersebut, sudah banyak penduduk di Indonesia, khususnya di pedesaan, yang sudah bekerja atau mencari pekerjaan. Dengan bertambahnya kegiatan pendidikan, maka jumlah penduduk dalam usia sekolah yang melakukan kegiatan ekonomi akan berkurang. Bila wajib belajar 9 tahun diterapkan, maka anak-anak sampai dengan umur 14 tahun akan berada di sekolah. Dengan kata lain, jumlah pnduduk yang bekerja dalam batas umur tersebut akan menjadi sangat kecil, sehingga batas umur minimum lebih tepat dinaikkan menjadi 15 tahun. Atas pertimbangan tersebut, Undang-Undang No.25 tahun 1997 tentang 
ketenagakerjaan telah menetapkan batas usia kerja menjadi 15 tahun. Dengan mulai berlakunya UU tersebut pada tanggal 1 oktober 1998, tenaga kerja didefinisikan sebagai penduduk berumur 15 tahun atau lebih (Mohamad Maulana, 2007).

Tenaga kerja (manpower) terdiri dari angkatan kerja dan bukan angkatan kerja. Angkatan kerja (labor force) terdiri dari golongan yang bekerja, golongan mengganggur dan mencari pekerjaan. Kelompok bukan angkatan kerja terdiri dari golongan yang bersekolah, mengurus rumah tangga dan lain-lain (penerima pendapatan). Ketiga golongan dalam kelompok angkatan kerja yang sewaktuwaktu dapat menawarkan jasanya untuk bekerja. Oleh sebab itu, kelompok ini sering juga dinamakan sebagai potential labor force.

Petumbuhan Tenaga Kerja atau jumlah serapan tenaga kerja secara sektoral, diukur dengan formula (Amirudin Syam, 2000):

$$
\begin{aligned}
& \text { PTK }=\frac{\text { Jumlah Tenaga Kerja tahun } k_{t}-\text { Jumlah Tenaga Kerja Tahun } t-1}{\text { Jah }} \\
& \text { Jumlah Tenaga Kerja Tahun } \mathrm{t}-1
\end{aligned}
$$

Elastisitas Kesempatan Kerja didefinisikan sebagai perbandingan laju pertumbuhan kesempatan kerja dengan laju pertumbuhan ekonomi, yang diukur dengan formula (Simanjutak, 1998):

$$
E=\frac{\text { Laju Pertumbuhan Kesempatan Kerja }}{\text { Laju Pertumbuhan Pendapatan Nasional }}
$$

Tingkat Pengangguran Terbuka (TPT) mengindikasikan tentang penduduk usia kerja yang termasuk dalam kelompok pengangguran, diukur dengan formula (Winarsih,2008):

$$
\mathrm{TPT}=\frac{\text { Jumlah Pengangguran }}{\text { Jumlah Angkatan Kerja }} \times 100 \%
$$

Analisis data dalam kajian ini mengenai kegiatan ekonomi penduduk dengan menitikberatkan pada alokasi angkatan kerja yang bekerja menurut sektor. Kontribusi sektor menggambarkan andil setiap sektor dalam menyerap tenaga kerja. Perubahan kontribusi sektor dalam penyerapan tenaga kerja dalam suatu 
kurun waktu merupakan indikasi perubahan struktur perekonomian suatu daerah. Pembagian angkatan kerja yang bekerja dan perkembangannya menurut sektor dianalisis dengan membedakan tiga sektor, yakni:

1. Sektor Primer, terdiri atas :

a. Sektor pertanian

b. Sektor pertambangan dan galian.

2. Sektor Sekunder, terdiri atas:

a. Sektor Industri Pengolahan

b. Sektor listrik, gas dan air

c. Sektor bangunan

3. Sektor Tersier, terdiri atas:

a. Sektor perdagangan, hotel dan restoran

b. Sektor pengangkutan dan komunikasi

c. Sektor keuangan, persewaan dan jasa perusahaan

d. Sektor jasa-jasa

Berbagai hasil penelitian menunjukkan bahwa telah terjadi pergeseran kontribusi terbesar dalam pertumbuhan ekonomi antar sektor di Indonesia, yakni dari sektor primer ke sektor sekunder dan tersier. Seperti apakah perubahan tersebut berlaku di provinsi Maluku?. Untuk melihat perubahan kontribusi pertumbuhan ekonomi antar sektor beserta penyerapan tenaga kerjanya, dapat ditelaah secara lebih kritis pada saat sebelum dan sesudah krisis ekonomi, dan sekaligus sebelum dan setelah otonomi daerah di provinsi Maluku. Selain itu, akan dikaji apakah peningkatan pertumbuhan ekonomi diikuti pula dengan penyerapan tenaga kerja. Analisis ini sangat penting bagi berbagai pihak yang kompeten dalam rangka pengambilan keputusan atau kebijakan yang terkait dengan masalah ketenagakerjaan.

\section{METODE ANALISIS}

Analisis data dilakukan dengan menggunakan metode statistik deskriptif. Analisis deskriptif antara lain dilakukan untuk memberikan gambaran komposisi penyerapan tenaga kerja dan PDRB antar sektor, kemudian berdasarkan formula yang ada dianalisis tingkat pertumbuhan ekonomi dan elastisitas kesempatan kerja 
yang dikelompokkan ke dalam tiga kelompok sektor besar (sektor primer, sektor sekunder dan sektor tersier) beserta perbandingan antara saat krisis ekonomi dan sebelum otonomi daerah dengan sesudah krisis ekonomi dan otonomi daerah. Analisis ini juga dilengkapi dengan tingkat penyerapan tenaga kerja dan yang tidak bekerja (pengangguran) berdasarkan tingkat pendidikan di Provinsi Maluku.

\section{Sumber Data Yang Digunakan}

Kajian ini menggunakan data sekunder. Data yang digunakan dalam kajian ini merupakan data series yang telah dirilis oleh BPS sejak tahun 1996 hingga 2007. Data jumlah tenaga kerja setiap sektor diperoleh dari statistik Keadaan Angkatan Kerja Indonesia, sedangkan data pertumbuhan ekonomi setiap sektor diperoleh dari statistik Produk Domestik Regional Bruto Provinsi-Provinsi Di Indonesia Menurut Lapangan Usaha.

\section{HASIL DAN PEMBAHASAN}

\section{Penyerapan Tenaga Kerja dan Kontribusi Nilai Tambah Bruto}

Manusia merupakan salah satu faktor terpenting dalam proses produksi, sehingga dapat dikatakan bahwa kesempatan kerja akan meningkat jika output meningkat atau sektor yang memperkerjakan banyak orang umumnya menghasilkan barang dan jasa yang relatif besar. Dalam tahun 1996, terdapat 73,5 $\%$ bekerja di sektor tersier yang memberikan kontribusi 41,3\% terhadap pendapat nasional. Sektor Primer menyerap 13,6 \% tenaga kerja dan memberikan kontribusi $32,3 \%$ terhadap pendapatan naional. Kemudian sektor sekunder menyerap 12,9\% tenaga kerja dan memberikan kontribusi 26,4 \% terhadap pendapatan nasional.

Namun pada tahun-tahun berikutnya, yakni dari tahun 1997 hingga tahun 2006 terjadi perubahan struktural antar sektor, baik dalam penyerapan tenaga kerja maupun dalam kontribusinya terhadap pendapatan nasional. Pada tahun-tahun tersebut, penyerapan tenaga kerja yang terbesar adalah di sektor primer, tetapi kontribusi terhadap pendapatan nasional yang terbesar bukanlah pada sektor primer melainkan pada sektor tersier. Apabila di urut, sektor yang paling banyak menyerap tenaga kerja adalah sektor primer, tersier kemudian sekunder. 
Sedangkan kontribusi terhadap pendapatan nasional berturut-turut adalah sektor tersier, primer dan sekunder.

Kondisi seperti ini dikategorikan ke dalam model pertumbuhan output dan kesempatan kerja yang bertentangan. Artinya meningkatnya kontribusi PDRB tetapi tidak diikuti oleh penyerapan tenaga kerja. Model yang saling bertentangan ini disebabkan oleh karena output maksimum tercipta oleh adanya industri dengan teknologi modern yang padat modal dan hemat penggunaan tenaga kerja.

$€$ Tabel 1

Komposisi Penyerapan Tenaga Kerja dan Nilai Tambah Bruto Menurut Sektor di Provinsi Maluku, 1996 - 2007 (\%)

\begin{tabular}{|c|c|c|r|r|c|c|}
\hline \multirow{2}{*}{ TAHUN } & \multicolumn{2}{|c|}{ PRIMER } & \multicolumn{2}{c|}{ SEKUNDER } & \multicolumn{2}{c|}{ TERSIER } \\
\cline { 2 - 7 } & TK & PDRB & TK & PDRB & TK & PDRB \\
\hline 1996 & $13,6 \%$ & $32,3 \%$ & $12,9 \%$ & $26,4 \%$ & $73,5 \%$ & $41,3 \%$ \\
\hline 1997 & $57,6 \%$ & $35,2 \%$ & $4,0 \%$ & $18,2 \%$ & $38,4 \%$ & $46,6 \%$ \\
\hline 1998 & $66,7 \%$ & $33,5 \%$ & $7,0 \%$ & $23,2 \%$ & $26,3 \%$ & $43,3 \%$ \\
\hline 1999 & $62,2 \%$ & $35,3 \%$ & $8,5 \%$ & $9,2 \%$ & $29,3 \%$ & $55,6 \%$ \\
\hline 2000 & $61,2 \%$ & $34,5 \%$ & $7,2 \%$ & $6,9 \%$ & $31,6 \%$ & $58,6 \%$ \\
\hline 2001 & $59,2 \%$ & $37,1 \%$ & $3,8 \%$ & $6,9 \%$ & $37,0 \%$ & $56,1 \%$ \\
\hline 2002 & $66,5 \%$ & $36,3 \%$ & $8,1 \%$ & $6,7 \%$ & $25,4 \%$ & $57,0 \%$ \\
\hline 2003 & $61,5 \%$ & $35,5 \%$ & $8,8 \%$ & $6,6 \%$ & $29,8 \%$ & $57,9 \%$ \\
\hline 2004 & $62,0 \%$ & $35,0 \%$ & $9,2 \%$ & $6,6 \%$ & $28,8 \%$ & $58,5 \%$ \\
\hline 2005 & $61,3 \%$ & $34,5 \%$ & $6,6 \%$ & $6,5 \%$ & $32,1 \%$ & $59,0 \%$ \\
\hline 2006 & $62,2 \%$ & $34,3 \%$ & $7,9 \%$ & $6,5 \%$ & $29,5 \%$ & $59,2 \%$ \\
\hline 2007 & $14,3 \%$ & $33,7 \%$ & $16,0 \%$ & $6,8 \%$ & $69,7 \%$ & $59,5 \%$ \\
\hline
\end{tabular}

Sumber: BPS. PDRB Propinsi-Propinsi di Indonesia Menurut Lapangan Usaha dan Keadaan Angkatan Kerja di Indonesia (diolah dari berbagai tahun terbitan).

Jika dilihat komposisi penyerapan tenga kerja maupun kontribusinya terhadap pendapatan nasional dari masing-masing sektor yang mengalami perubahan struktur tersebut, angkanya mengalami fluktasi atau tidak mencerminkan tren yang naik maupun turun. Khusus untuk tahun 2007, terjadi perubahan struktur yang berbeda dari tahun-tahun sebelumnya. Sektor tersier 
kembali menjadi sektor yang menyerap banyak tenaga kerja dan kontribusi terhadap pendapatan nasionalnyapun ikut besar, kemudian disusul sektor sekunder dan primer yang banyak menyerap tenaga kerja. Namun untuk kontribusi pendapatan nasional sektor primerlah yang menyumbang pendapatan nasional terbesar dari pada sektor sekunder. Keadaan tersebut menunjukkan bahwa ternyata pergerakan indikator ketenagakerjaan tidak selalu menunjukkan harmonisasi hubungan dengan pergerakan indikator perekonomian (PDRB).

Ditinjau dari seluruh sektor perekonomian secara total, transformasi terjadi dalam bentuk turunnya sumbangan sektor primer dalam GDP dan kesempatan kerja yang diciptakannya. Ini bisa terjadi dengan meningkatnya standar hidup masyarakat secara umum, kebutuhan konsumsi barang dan jasa non-pangan meningkat, sehingga meningkatkan proporsi sumber daya yang dialokasikan untuk proses produksi sektor non primer.

Menurut Arsyad (1987) dalam Abdul Hakim (2004), terjadinya transformasi atau perubahan struktur sektor pertanian (sektor primer) ini dapat disebabkan oleh karena di sektor pertanian mengalami tahap-tahap perkembangan atau transformasi sebagai berikut:

1. Tahap pertanian subsisten, yaitu suatu tahap di mana produksi dan konsumsi berjumlah seimbang sehingga tidak ada kelebihan yang bisa dijual ke pasar. Jenis tanamannya terbatas pada beberapa tanaman bahan pangan pokok seperti padi, jagung, atau ketela. Produksi dan produktifitas rendah karena menggunakan peralatan sederhana dengan teknologi rendah, yang mendominasi adalah tanah dan tenaga kerja manusia. Pada tahap ini motif utama para petani adalah untuk bertahan hidup, bukan untuk meningkatkan produktifitas.

2. Tahap transisi, yaitu tahap perpindahan dari pertanian subsisten ke pertanian medern. Seiring dengan tersebarnya informasi dan bertambahnya pendidikan di antara keluarga petani, minat mereka akan jenis tanaman serta teknologi baru dan penggunaan modal dalam proses pertanian mereka semakin besar.

3. Tahap pertanian modern, yaitu tahap di mana jenis tanaman yang dibudidayakan murni ditujukan untuk pasar. Modal dan peralatan mekanis serta penggunaan bibit dan pupuk buatan dan lain-lainnya sudah mendominasi 
pertanian. Proses produksi dikendalikan oleh sebuah manajemen yang mengontrol proses pertanian dan juga serta kondisi bisnis di perekonomian secara umum.

\section{Elastisitas Kesempatan Kerja}

Elastisitas kesempatan kerja adalah nilai yang menunjukkan persentase peningkatan jumlah tenaga kerja yang dapat diserap di sektor i jika terjadi peningkatan nilai tambah bruto di sektor i sebesar $1 \%$. Normalnya, nilai elastisitas kesempatan kerja lebih kecil dari pada satu karena hal tersebut menunjukkan bahwa pertumbuhan nilai tambah bruto lebih cepat dari pada pertumbuhan kesempatan kerja yang diciptakannya. Sedangkan apabila nilai elastisitas kesempatan kerja lebih besar dari pada satu berarti terjadi penurunan produktifitas per tenaga kerja atau terjadinya underemployment di sektor yang bersangkutan (Hera Susanti, 2007). Nilai elastisitas kesempatan kerja antar sektor primer, sekunder dan tersier dapat dilihat pada tabel berikut.

Tabel 2

Elastisitas Kesempatan Kerja Antar Sektor di Provinsi Maluku

\begin{tabular}{|c|r|r|r|}
\hline TAHUN & PRIMER & SEKUNDER & TERSIER \\
\hline 1997 & -130 & $-7,7$ & 0,6 \\
\hline 1998 & -34 & 16,9 & 4 \\
\hline 1999 & 0,6 & $-0,7$ & $-0,6$ \\
\hline 2000 & 0,3 & 0,9 & $-59,0$ \\
\hline 2001 & $-0,5$ & $-0,6$ & $-0,2$ \\
\hline 2002 & 1,9 & 0,08 & 0,07 \\
\hline 2003 & $-16,3$ & $-5,09$ & $-0,6$ \\
\hline 2004 & 37,3 & 32,6 & $-0,3$ \\
\hline 2005 & $-0,5$ & $-3,4$ & 0,5 \\
\hline 2006 & 6,4 & $-1,5$ & 0,4 \\
\hline 2007 & $-1,4$ & 11,5 & $-7,3$ \\
\hline
\end{tabular}

Sumber: BPS. PDRB Propinsi-Propinsi di Indonesia Menurut Lapangan Usaha dan Keadaan Angkatan Kerja di Indonesia (diolah dari berbagai tahun terbitan). 
Pada umumnya, sektor dengan nilai produktifitas per tenaga kerja yang mengalami kenaikan adalah sektor tersier. Artinya, pertumbuhan nilai tambah bruto di sektor tersier lebih cepat dari pada pertumbuhan kesempatan kerja yang diciptakannya. Berdasarkan tabel 2 tersebut, sektor yang mempunyai nilai elastisitas kesempatan kerja lebih besar dari pada satu adalah sektor sekunder dan tersier pada tahun 1998 masing-masing sebesar 16,9 dan 4, kemudian tahun 2004 adalah sektor primer 37,3 dan sektor sekunder 32,6. Selanjutnya sektor primer di tahun 2002 dan 2006 sebesar 1,9 dan 6,4, sedangkan tahun 2007 sebesar 11,5 di sektor sekunder. Angka elastisitas negatif terjadi pada semua sektor, namun yang cukup besar angkanya adalah sektor primer. Ini berarti penambahan output di sektor tersebut hanya dilakukan dengan cara mengurangi tenaga kerja. Artinya, peningkatan produksi hanya bisa dilakukan dengan memasukan faktor teknologi dan mengurangi pekerja.

Secara keseluruhan, sektor yang dominan mempunyai produktifitas per tenaga kerjanya yang rendah adalah sektor primer dan sekunder. Kalau laju pertumbuhan produktifitas sektor primer dan sekunder lebih rendah dari rata-rata sektor tersier, maka penurunan kontribusi sektor primer dan sekunder dalam menyerap tenaga kerja cenderung lebih lambat dari pada penurunan kontribusinya dalam PDB.

Transformasi ketenagakerjaan menurut lapangan pekerjaan ini erat kaitannya dengan transformasi struktur produksi dan perbedaan pertumbuhan produktifitas per pekerja menurut sektor atau lapangan pekerjaan yang terjadi selama pertumbuhan ekonomi berlangsung. Menurut Aris Ananta (1993), perkembangan produktifitas per pekerja di suatu negara atau daerah biasanya dipengaruhi oleh:

1. Perkembangan stok barang modal per pekerja

2. Perkembangan mutu tenaga kerja, yang tercermin pada perbaikan pendidikan, ketrampilan dan kesehatan pekerja

3. Peningkatan skala unit usaha

4. Pergeseran pekerja dari kegiatan yang relatif lebih rendah produktifitasnya ke yang lebih tinggi 
5. Perubahan product mix atau komposisi output pada masing-masing sektor atau sub-sektor

6. Pergeseran teknik produksi dari padat karya ke padat modal.

Proses akumulasi yang terjadi selama pertumbuhan ekonomi pada umumnya menyebabkan produktifitas pekerja pada tiap-tiap lapangan pekerjaan mengalami kenaikan. Namun demikian karena proses akumulasi yang terjadi pada masing-masing sektor dan lapangan pekerjaan tidak terjadi dengan kecepatan yang sama, perkembangan produktifitas pada masing-masing sektor dan lapangan pekerjaan juga berbeda-beda. Proses akumulasi di sektor pertanian (sektor primer) biasanya berlangsung lebih lambat dari sektor-sektor non pertanian, sehingga laju pertumbuhan produktifitas di sektor tersebut menjadi lebih lambat dari sektorsektor non pertanian.

\section{Ketenagakerjaan dan Pertumbuhan Ekonomi Sektoral Saat Krisis Ekonomi / Sebelum Otonomi Daerah dan Sesudahnya : Sebuah Perbandingan}

Periode krisis sejak pertengahan tahun 1997 menjadi potret suram ketenagakerjaan di Indonesia. Kisah ini di awali dengan tekanan nilai tukar yang sedemikian besar terhadap sektor riil di Indonesia yang mengakibatkan bangkrutnya sektor riil di Indonesia. Hal ini berdampak pada Pemutusan Hubungan Kerja (PHK) besar-besaran baik akibat tutupnya industri-industri yang tidak lagi sanggup menahan besarnya tekanan krisis ekonomi, maupun industriindustri yang mengambil langkah-langkah efisiensi atau lebih tepatnya pengurangan kapasitas produksi. Periode berikutnya adalah periode politik yang diikuti dengan konflik dan kekacauan di berbagai daerah. Reformasi politik yang memberikan dampak negatif kekacauan, penjarahan, pengambilalihan unit-unit usaha serta konflik diberbagai daerah termasuk di dalamnya adalah provinsi Maluku, telah menciptakan instabilitas dalam politik dan keamanan yang menyebabkan hengkangnya investor asing dan bahkan investor dalam negeri yang juga berdampak pada semakin kecilnya tingkat pertumbuhan ekonomi maupun tingkat penyerapan tenaga kerja. 
Tabel 5

Rata-Rata Tingkat Pertumbuhan Kesempatan Kerja (TKK) dan Tingkat Pertumbuhan Ekonomi (TPE) antar Sektor saat Krisis Ekonomi dan Otonomi Daerah maupun Sesudah Krisis Ekonomi dan Otonomi Daerah di Provinsi Maluku

\begin{tabular}{|c|r|r|r|r|r|r|}
\hline \multirow{2}{*}{ TAHUN } & \multicolumn{2}{|c|}{ PRIMER } & \multicolumn{2}{c|}{ SEKUNDER } & \multicolumn{2}{c|}{ TERSIER } \\
\cline { 2 - 7 } & TPKK & \multicolumn{1}{c|}{ TPE } & TPKK & \multicolumn{1}{c|}{ TPE } & TPKK & \multicolumn{1}{c|}{ TPE } \\
\hline 1997 & $912 \%$ & $-7 \%$ & $101 \%$ & $-13,3 \%$ & $211 \%$ & $6 \%$ \\
\hline 1998 & $34 \%$ & $-10 \%$ & $310 \%$ & $-5 \%$ & $-8 \%$ & $-1,75 \%$ \\
\hline 1999 & $-42 \%$ & $-66 \%$ & $49 \%$ & $-69,7 \%$ & $2 \%$ & $-27,3 \%$ \\
\hline 2000 & $-6 \%$ & $-21,5 \%$ & $-15 \%$ & $-16,3$ & $-15 \%$ & $0,3 \%$ \\
\hline 2001 & $-64,5 \%$ & $125,5 \%$ & $-72,3 \%$ & $126,3 \%$ & $-20 \%$ & $92,8 \%$ \\
\hline 2002 & $159 \%$ & $81 \%$ & $8 \%$ & $94,7 \%$ & $8 \%$ & $104,3 \%$ \\
\hline 2003 & $-49 \%$ & $3 \%$ & $-29 \%$ & $5,7 \%$ & $-4 \%$ & $7 \%$ \\
\hline 2004 & $112 \%$ & $3 \%$ & $196 \%$ & $5,3 \%$ & $-2 \%$ & $6 \%$ \\
\hline 2005 & $-2 \%$ & $4 \%$ & $-17 \%$ & $5,3 \%$ & $3 \%$ & $6,2 \%$ \\
\hline 2006 & $32 \%$ & $60 \%$ & $-9 \%$ & $8,3 \%$ & $16 \%$ & $6,2 \%$ \\
\hline 2007 & $-85 \%$ & $60 \%$ & $92 \%$ & $8,3 \%$ & $-44 \%$ & $6,2 \%$ \\
\hline
\end{tabular}

Sumber: BPS. PDRB Propinsi-Propinsi di Indonesia Menurut Lapangan Usaha dan Keadaan Angkatan Kerja di Indonesia (diolah dari berbagai tahun terbitan).

Berdasarkan data tersebut, selama krisis ekonomi dan sebelum adanya otonomi daerah dari tahun 1997 hingga tahun 1999, hanya sektor tersier pada tahun 1997 dan sektor sekunder pada tahun 1998 yang mengalami tingkat pertumbuhan ekonomi positif, sedangkan sektor primer dan tahun-tahun lainnya selama krisis ekonomi berlangsung, mengalami tingkat pertumbuhan ekonomi negatif. Namun yang yang paling mengesankan adalah, ketika pertumbuhan ekonomi menurun dan bahkan mencapai angka negatif tetapi tingkat penyerapan tenaga kerja tetap besar.

Hal ini terjadi pada semua sektor, namun sebahagian besar terjadi pada tahun 1997 dan 1998 dalam sektor primer dan tahun 1997 hingga tahun 1999 pada sektor sekunder. Bukti empiris selama krisis menunjukkan bahwa tatkala sektor tersier mengalami kontraksi hebat, tingkat pertumbuhan kesempatan kerja sektor 
primer dan sekunder tetap mampu tumbuh positif walaupun tingkat pertumbuhan ekonomi mengalami penurunan hingga mencapai minus. Tatkala sektor tersier melakukan Pemutusan Hubungan Kerja (PHK) besar-besaran, penyerapan tenaga kerja di sektor primer dan sekunder justru meningkat tajam. Fakta tersebut memberikan gambaran bahwa kontribusi langsung sektor primer dan sekunder dalam penyerapan tenaga kerja masih sangat besar di tengah krisis ekonomi. Hal ini terjadi karena adanya krisis ekonomi menyebabkan berpindahnya tenaga kerja yang di PHK dari sektor tersier ke sektor primer dan sekunder, mengingat sektor primer bersifat akomodatif terhadap penyerapan tenaga kerja karena sifatnya yang tidak menuntut persyaratan kerja yang berlebihan sehingga bertambahnya jumlah pekerja. Selain itu, adanya kebijaksanaan pemerintah untuk memanfaatkan lahanlahan tidur untuk usaha pertanian terutama di kota sehingga dapat menampung tenaga kerja yang di PHK dari sektor tersier yang mengalami penurunan produksi.

Setelah otonomi daerah yang dilakukan pada tahun 2001 dan berakhirnya krisis ekonomi, tingkat pertumbuhan ekonomi mengalami peningkatan yang sangat tajam pada tahun 2001 hingga tahun 2007 dengan tingkat kesempatan kerja yang tumbuh dengan positif maupun negatif. Angkanya berfluktuatif pada setiap tahun dan berfariasi antar sektor. Dengan demikian, maka dapat disimpulkan bahwa secara keseluruhan tingkat pertumbuhan ekonomi selama krisis tidak lebih baik dari pada setelah krisis ekonomi berlalu dan adanya otonomi daerah.

\section{Ketenagakerjaan dan Pendidikan}

Titik singgung antara pendidikan dan pertumbuhan ekonomi ialah produktifitas tenaga kerja, dengan asumsi bahwa semakin tinggi mutu pendidikan, semakin tinggi produktifitas tenaga kerja, dan semakin tinggi pula pengaruhnya terhadap pertumbuhan ekonomi suatu masyarakat. Pengertian ini diyakini oleh suatu teori yang dinamakan teori human capital. Teori ini menerangkan bahwa pendidikan memiliki pengaruh terhadap pertumbuhan ekonomi melalui peningkatan produktifitas tenaga kerja. Teori ini meyakini bahwa pertumbuhan suatu masyarakat harus dimulai dari produktifitas individu. Jika setiap individu memiliki hasil yang lebih tinggi karena memperoleh pendidikan yang lebih tinggi, maka pertumbuhan ekonomi masyarakat dapat ditunjang karenanya. Teori human 
capital menganggap bahwa pendidikan formal merupakan suatu investasi baik bagi individu maupun bagi masyarakat.

Namun demikian, sering dijumpai kenyataan empiris bahwa asumsi-asumsi yang digunakan oleh teori human capital tidak selalu benar dalam kenyataannya. Di provinsi Maluku ternyata menunjukkan kecenderungan yang sama. Pendidikan formal hanya memberikan kontribusi lebih kecil terhadap kesempatan kerja dibandingkan dengan latar belakang keluarga dan faktor-faktor luar sekolah lainnya. Hal ini dibuktikan dengan menyimak data-data berikut ini.

Tabel 3

Tingkat Kesempatan Kerja Berdasarkan Tingkat Pendidikan di Provinsi Maluku

\begin{tabular}{|c|c|c|c|c|}
\hline Tahun & SD & SMP $^{*}$ & SMA $^{*}$ & Universitas \\
\hline 1997 & $37 \%$ & $18 \%$ & $19 \%$ & $2 \%$ \\
\hline 1998 & $43 \%$ & $20 \%$ & $18 \%$ & $1 \%$ \\
\hline 1999 & $41 \%$ & $23 \%$ & $20 \%$ & $1 \%$ \\
\hline 2003 & $34 \%$ & $26 \%$ & $22 \%$ & $1 \%$ \\
\hline 2004 & $33 \%$ & $27 \%$ & $21 \%$ & $2 \%$ \\
\hline 2005 & $28 \%$ & $24 \%$ & $5 \%$ & $2 \%$ \\
\hline 2006 & $32 \%$ & $21 \%$ & $17 \%$ & $2 \%$ \\
\hline 2007 & $35 \%$ & $17 \%$ & $22 \%$ & $3 \%$ \\
\hline
\end{tabular}

Sumber : BPS. Keadaan Angkatan Kerja Indonesia. (diolah dari berbagai tahun terbitan)

*Angka SMP dan SMA sudah termasuk SMP dan SMA Kejuruan.

Menurut data yang ada tersebut, kontribusi lulusan Universitas atau perguruan tinggi bervariasi sebesar $1 \%$ sampai dengan $3 \%$. Angka tersebut sangat jauh dengan lulusan SD yang paling tertinggi sebesar $43 \%$ pada tahun 1998, sedangkan angkanya dari tahun ke tahun mengalami fluktuasi (naik turun) dan tidak ada tren penurunan yang signifikan. Keadaan tersebut terjadi pula pada tamatan SMP dan SMA, tidak ada tren penurunan kontribusi lulusan tersebut yang berarti. Hanya pada tahun 2005 saja, pekerja lulusan SMA berkontribusi sebesar 5 \%. Selama tahun 1997 sampai dengan tahun 2007, pekerja lulusan SMP berkisar 
antara $17 \%$ sampai dengan $27 \%$, sedangkan lulusan SMA berkisar antara $17 \%$ sampai dengan $22 \%$.

Keragua-raguan yang sering terlontar dari kalangan para peneliti terhadap asumsi teori human capital memang cukup beralasan. Pertama, lapangan kerja, khususnya sektor modern yang bersifat remuneratif sangat terbatas jumlahnya, sehingga tenaga kerja terdidik yang berjumlah besar dan muncul dalam waktu yang bersamaan sering tidak dapat ditampung oleh lapangan kerja yang tersedia di sektor tersebut. Kedua, kenyataan umum menunjukkan bahwa lulusan pendidikan belum siap untuk bekerja sesuai harapan lapangan kerja, sehingga banyak dunia usaha-industri yang masih harus melatih tenaga tersebut dalam waktu yang relatif lama agar mereka dapat bekerja.

Walaupun relevansi pendidikan masih merupakan konsep yang belum jelas dan masih terus diperdebatkan. Banyak kalangan berpendapat bahwa salah satu penyebab rendahnya produktifitas tenaga kerja sektor pertanian (sektor primer) adalah rendahnya tingkat pendidikan para petaninya. Dengan demikinan, maka terjadinya penurunan produktifitas per tenaga kerja di sektor primer dan sekunder di sebabkan oleh karena tenaga kerja yang terserap ke dalam kedua sektor tersebut pada umumnya di isi oleh tenaga kerja yang hanya lulusan Sekolah Dasar (SD), yang kemudian diikuti oleh pekerja lulusan Sekolah Menegah Pertama (SMP) dan Sekolah Menengah Atas (SMA). Dengan tingkat pendidikan yang rendah maka adopsi teknologi tidak berjalan secara optimal, sehingga upaya peningkatan produksi per satuan luas (produktifitas) sulit dilakukan. Jadi, pendidikan memang dibutuhkan untuk mendukung kemampuan seseorang dalam bekerja, walaupun hal tersebut tidaklah mutlak.

\section{Gejala Pengangguran Terdidik}

Pengangguran di antara penduduk yang berpendidikan (terdidik) timbul akibat adanya penyesuaian tenaga kerja bagi penduduk yang baru menyelesaikan pendidikan (tamat sekolah). Salah satu faktor pendorong pengangguran terdidik adalah struktur upah bergerak sangat lambat, khususnya pada sektor jasa merupakan lapangan kerja dominan bagi pekerja-pekerja terdidik. Mekanisme penentuan tingkat upah yang tidak konsisten antar output pendidikan dan 
kesempatan kerja juga memberikan kontribusi pada terjadinya pengangguran terdidik. Dengan demikian peduduk yang baru menyelesaikan pendidikan cendeung untuk menunggu hingga mendapatkan pekerjaan yang memberikan balas jasa lebih baik dari pada langsung menerima pekerjaan dengan upah/gaji yang rendah.

Di tengah upaya pemerintah mengurangi Tingkat Pengangguran Terbuka (TPT) di Indonesia, realitas menunjukkan trend TPT bagi tenaga kerja terdidik (mengacu pada kelompok SMA dan pendidikan tinggi) cenderung meningkat.

Tabel 4

Tingkat Penggangguran Terbuka (TPT) Berdasarkan Tingkat Pendidikan di Provinsi Maluku

\begin{tabular}{|c|c|c|c|c|}
\hline Tahun & SD & SMP & SMA & Universitas \\
\hline 1997 & 0 & $1 \%$ & $4 \%$ & 0 \\
\hline 1998 & 0 & $1 \%$ & $2 \%$ & 0 \\
\hline 1999 & 0 & $1 \%$ & $4 \%$ & 0 \\
\hline 2003 & $1 \%$ & $2 \%$ & $8 \%$ & 0 \\
\hline 2004 & $2 \%$ & $2 \%$ & $6 \%$ & 0 \\
\hline 2005 & $1 \%$ & $1 \%$ & $6 \%$ & 0 \\
\hline 2006 & $3 \%$ & $4 \%$ & $7 \%$ & 0 \\
\hline 2007 & $2 \%$ & $2 \%$ & $6 \%$ & $1 \%$ \\
\hline
\end{tabular}

Sumber : BPS. Keadaan Angkatan Kerja Indonesia. (diolah dari berbagai tahun terbitan)

Pada tahun 1997 sampai dengan tahun 2007, tidak ada pengangguran bagi tenaga kerja yang lulusan SD atau tingkat penganggurannya adalah $0 \%$. Sedangkan pada tahun berikutnya, tingkat pengangguran bervariasi dari $1 \%$ hingga $3 \%$. Tingkat pengangguran lulusan SMP berkisar antara $1 \%$ hingga $4 \%$. Kondisi tersebut tidak sebaik tingkat pengangguran tamatan SMA dengan tingkat pengangguran sebesar $2 \%$ hingga $8 \%$. Berfluktuasinya tingkat pengangguran lulusan SD, SMP dan SMA tersebut sangat berbeda dengan kondisi tingkat pengangguran pada tingkat Universitas. Seperti yang terlihat pada tabel 4, dari 
tahun 1997 hingga tahun 2006, tidak ada penggangguran bagi tenaga kerja lulusan perguruan tinggi.

Namun setelah tahun 2007, seiring dengan semakin banyaknya lulusan perguruan tinggi memasuki pasar tenaga kerja yang tidak sebanding dengan lapangan kerja yang tersedia, maka terdapat tingkat pengangguran sebesar $1 \%$. Besarnya angka pengagguran terdidik ini sungguh memprihatinkan, perjuangan mereka menempuh pendidikan berakhir dengan sulitnya mendapatkan pekerjaan. Disisi lain, mereka merupakan sumber daya potensi yang selayaknya terakomodasi untuk memacu laju pembangunan ekonomi provinsi Maluku. Munculnya pengangguran terdidik tersebut, salah satu faktor penyebabnya adalah lapangan kerja yang berkembang cenderung di dominasi oleh sektor-sektor subsisten yang tidak membutuhkan tenaga kerja terdidik. Selain itu, munculnya pengangguran terdidik tersebut dapat di indikasikan bahwa pasar tenaga kerja tidak berjalan secara efektif dan efisien seperti kurang baiknya informasi pasar tenaga kerja.

Sejalan dengan upaya penurunan angka pengangguran oleh pemerintah, masalah pengangguran terdidik ini menjadi sangat penting untuk diperhatikan. Hal ini disebabkan karena pada umunya jenis dan tingkat pendidikan dianggap dapat mewakili tenaga kerja. Pendidikan adalah suatu proses yang bertujuan untuk menambah ketrampilan, pengetahuan, dan meningkatkan kemandirian maupun pembentukan kepribadian seseorang (Arfida, 2003). Aspirasi mereka untuk bekerja perlu dipertimbangkan dengan segera mengingat mereka merupakan sumber daya potensi yang perlu diberdayakan dalam pembangunan.

\section{Kebijakan Ketenagakerjaan}

\section{a. Link and Match Lembaga Pendidikan dengan Pasar Kerja}

Proses penyiapan tenaga kerja bukanlah hal yang mudah. Kemampuan seorang tenaga kerja untuk masuk dalam lapangan kerja diperoleh dari bangku sekolah. Banyak lapangan kerja yang membutuhkan keterampilan tertentu yang harus diperoleh tenaga kerja dari berbagai sumber. Salah satu kendala dalam proses penyiapan tenaga kerja antara lain adalah belum sejalannya kurikulum sekolah dan perguruan tinggi dengan kebutuhan lapangan kerja daerah. Hingga saat ini perusahaan sebagai pihak yang membutuhkan tenaga kerja relatif belum 
melakukan kerjasama dengan lembaga pendidikan yang ada untuk menyusun kurikulum sesuai dengan kualifikasi yang dibutuhkan. Dengan demikian pemerintah perlu menjadi fasilitator antara lembaga pendidikan sebagai penyedia tenaga kerja berkualitas dengan sektor-sektor usaha sebagai peminta tenaga kerja. Hal ini perlu dilakukan untuk memastikan link and match dunia pendidikan dengan kebutuhan tenaga kerja.

b. Hubungan Industrial Ketenagakerjaan

Pengusaha, tenaga kerja, dan pemerintah dengan kebijakan daerahnya merupakan tri-partit dalam pembangunan perekonomian daerah. Bila hubungan antara ketiganya berjalan sesuai dengan fungsinya dan aturan yang berlaku, maka permasalahan ketenagakerjaan dapat diminimalisir. Pemerintah dapat menjamin keberlangsungan investasi modal oleh pengusaha dengan menciptakan keamanan dan kenyamanan berusaha. Dengan demikian pengusaha akan mampu memberi hak-hak tenaga kerja yang membuat tenaga kerja merasa nyaman bekerja dan dapat meningkatkan produktivitas tenaga kerja. Hal ini pada akhirnya akan meningkatkan perekonomian daerah. Hubungan antara pengusaha, tenaga kerja dan pemerintah daerah-daerah di Maluku belum berjalan dengan baik. Masalahmasalah ketenaga-kerjaan sering timbul dalam perusahaan akibat ketidakmampuan pengusaha membayar upah minimum.

Masyarakat sebagai penyedia jasa tenaga kerja, menjadi sangat proaktif untuk memperjuangkan hak-haknya. Sayangnya, para tenaga kerja dan pelaku usaha sulit untuk menentukan titik temu baru bagi penyesuaian-penyesuaian yang ingin dilakukannya. Ditambah lagi, pemerintah tidak dapat berperan sebagai penengah yang baik bagi kedua kepentingan ini, dan pada banyak hal justru memberikan batu sandungan bagi kedua belah pihak. Dengan demikian maka, dibutuhkan peran dan interaksi antara masyarakat sebagai penyedia tenaga kerja, pelaku usaha sebagai pengguna jasa tenaga kerja dan pemerintah sebagai regulator dan stabilitator. 


\section{KESIMPULAN}

Dari uraian tentang ketenegakerjaan antar sektor dan kontribusi PDRB di atas, terdapat beberapa poin penting.

1. Sejalan dengan proses transformasi struktur produksi yang terjadi selama pertumbuhan ekonomi, struktur ketenagakerjaan juga mengalami pergeseran. Namun demikian, pergeseran pada struktur ketenagakerjaan terjadi lebih lambat dari pada yang terjadi pada struktur produksi. Ketimpangan antara pergeseran struktur PDRB dan ketenagakerjaan tersebut berkaitan erat dengan perkembangan tiap sektor pembangunan. Sektor primer masih mendominasi perekonomian Provinsi Maluku, namun dengan kecenderungan menurun. Penurunan sektor primer ini diikuti dengan meningkatnya sekunder dan tersier. Salah satu penyebab penurunan ini antara lain karena tidak banyak orang yang mau bekerja di lapangan usaha sektor primer karena dianggap kurang bergengsi dan menguntungkan.

2. Dalam kurun waktu 1997 hingga 2007, perekonomian Provinsi Maluku tumbuh lebih tinggi dibandingkan pertumbuhan penyerapan tenaga kerja. Hal ini menunjukkan bahwa hasil perekonomian Provinsi Maluku berkembang cukup baik, namun belum disertai dengan penyerapan tenaga kerja yang baik. Situasi di atas menyebabkan potensi tenaga kerja terdidik yang terus tumbuh di Provinsi Maluku tidak terserap, dan meningkatkan angka pengangguran di Provinsi Maluku.

3. Produktifitas per tenaga kerja di propinsi Maluku masih rendah, hal ini disebabkan oleh karena masih dominannya pekerja yang hanya tamatan sekolah dasar dan sekolah menengah pertama. Produktifitas tenaga kerja erat kaitannya dengan kualitas tenaga kerja dan human capital investment. Semakin tinggi human capital investment, semakin tinggi pula kualitas tenaga kerja (baik dari segi pendidikan, kesehatan, ketrampilan maupun lainnya). Dalam pasar tenaga kerja, semakin tinggi tingkat produktifitas semakin tinggi pula perannya dalam penciptaan output. Peningkatan produktifitas akan memperbaiki posisi tawar dari tenaga kerja itu sendiri di luar kebijakan pemerintah. 
4. Semakin besarnya angkatan kerja yang masuk ke pasar tenaga kerja menyebabkan supply tenaga kerja (tenaga kerja baru dan pengangguran) yang melonjak tinggi dibandingkan dengan permintaan yang semakin menurun. Selama krisis ekonomi (1997-1999), sektor tersier sebagian besar memberikan kontribusi yang negatif terhadap pertumbuhan penyerapan tenaga kerja. Sementara sektor primer dan sekunder berperan sebagai penampung tenaga kerja dari sektor tersier sehingga memberikan kontribusi yang positif terhadap pertumbuhan penyerapan tenaga kerja. Setelah otonomi daerah tahun 2001, tingkat pertumbuhan ekonomi dan penyerapan tenaga kerja tumbuh di semua sektor atau terjadi peningkatan.

5. Pembangunan ekonomi ditentukan oleh bagaimana para pelaku ekonomi berperan dalam berinteraksi dalam berbagai aspek pembangunan. Kurangnya keterkaitan antara lembaga pendidikan sebagai lembaga penyedia tenaga kerja dengan sektor usaha sebagai peminta tenaga kerja di daerah ini menyebabkan banyak tamatan lembaga pendidikan tidak terserap dalam lapangan kerja yang ada. Dalam konteks tenaga kerja, masyarakat sebagai penyedia faktor tenaga kerja, pengusaha sebagai pengguna faktor tenaga kerja sedangkan pemerintah sebagai regulator dan stabilisator dalam pasar tenaga kerja.

\section{SARAN}

Solusi dari berbagai permasalahan dalam ketenagakerjaan di provinsi Maluku tentunya kembali pada perbaikan, penataan kembali dan peningkatan performa fundamental ketenagakerjaan di provinsi Maluku itu sendiri. Beberapa hal yang penting menjadi perhatian bagi seluruh stakeholder ketenagakerjaan adalah:

1. Pertumbuhan ekonomi hendaknya diarahkan untuk dapat menyerap tenaga kerja yang lebih besar. Pemerintah Provinsi Maluku perlu lebih memperhatikan sektor primer karena sektor ini cukup banyak menyerap tenaga kerja dengan pendidikan dasar dan menengah. Sementara itu perkembangan sektor ini cenderung menurun, dan diikuti peningkatan sektor sekunder dan sektor tersier yang relatif sedikit membutuhkan tenaga kerja. Diperlukan peningkatan 
kesadaran masyarakat agar tetap bangga bekerja di sektor pertanian karena sektor ini layak dipertahankan di Provinsi Maluku.

2. Pengelolaan anggaran pemerintah yang benar-benar berimbang antara alokasi anggaran belanja aparatur daerah dan belanja pelayanan publik sehingga benar-benar dapat memberikan dana yang cukup tinggi bagi sektor ketenagakerjaan, pendidikan, kesehatan dan sektor-sektor vital lainnya dalam pembangunan. Pemerintah provinsi Maluku diharapkan benar-benar dapat menciptakan stimulus fiskal bagi perluasan tenaga kerja.

3. Sektor pendidikan hendaknya menjadi satu skala prioritas dalam kerangka perencanaan pembangunan ekonomi provinsi Maluku. Tenaga kerja yang berkualitas, infrastruktur yang memadai dan peningkatan taraf hidup tenaga pendidikan menjadi modal utama dalam pembangunan sektor pendidikan yang pada gilirannya akan meningkatkan kualitas dan produktifitas tenaga kerja.

4. Masalah supply-demand dalam ketenagakerjaan di provinsi Maluku patut mendapat perhatian semua pihak. Surplus tenaga kerja dapat diatasi dengan investasi sektor-sektor produktif baik dari pemerintah maupun terlebih diatasi oleh sektor swasta. Tentunya hal in juga harus dibarengi dengan human capital investment baik dari masyarakat sebagai pemilik faktor tenaga kerja, pelaku usaha maupun pemerintah. Dengan demikian akan memberikan stimulus yang cukup besar bagi peningkatan pendapatan dan penyerapan tenaga kerja.

5. Dituntut peran seluruh pihak baik masyarakat, pelaku usaha maupun pemerintah untuk dapat menciptakan lingkungan politik dan keamanan yang kondusif bagi investasi di Maluku sehingga pada gilirannya juga akan memberikan kesempatan yang lebih luas bagi tenaga kerja di Maluku. 


\section{DAFTAR PUSTAKA}

Ananta Aris. 1993. Ciri Demografis Kualitas Penduduk dan Pembangunan Ekonomi.. Lembaga Demografi, Fakultas Ekonomi Universitas Indonesia, Jakarta.

Arfida BR. 2003. Ekonomi Sumber Daya Manusia.. Ghalia Indonesia, Jakarta.

Badan Pusat Satitistik. 1996 - 2007. Produk Domestik Bruto Propinsi-Propinsi di Indonesia Menurut Lapangan Usaha. Jakarta. 1996 - 2007. Keadaan Angkatan Kerja di Indonesia. Jakarta.

Hakim Abdul. 2004. Ekonomi Pembangunan. Ekonisia, FE - UII. Yogyakarta

Mantra Ida Bagus. 2004. Demografi Umum. Edisi Kedua.. Pustaka Pelajar, Yogyakarta

Maulana Mohamad, Sudi Mardianto dan A. Husni Mailan. 2007. Dinamika Tenaga Kerja Sektor Pertanian di Indonesia. Jurnal Ekonomi Rakyat. www.ekonomirakyat.org.

Siamnjutak Payaman J. 1998. Pengantar Ekonomi Sumber Daya Manusia. Edisi Kedua.. Fakultas Ekonomi Universitas Indonesia. Jakarta.

Susanti Hera, Moh.Ikhsan dan Widyanti. 2007. Indokator-Indikator Makroekonomi.. Fakultas Ekonomi Universitas Indonesia. Jakarta

Syam Amiruddin dan Khairina M. Noekman. 2002. Kontribusi Sektor Pertanian Dalam Penyediaan Lapangan Kerja dan Perbandingannya Dengan Sektor-Sektor Lain.. Pusat Litbang Ekonomi Pertanian, Departemen Pertanian, R.I, Bogor

Winarsih Wachyu dan Nursahrizal. 2008. Analisis Pengangguran Terdidik. Badan Pusat Statistik. Jakarta. 
